\title{
Developing and Validating a Scale to Assess Organizational Behavior Foundations
}

\author{
Jafar Torkzadeh \\ Associate Professor of Educational Administration and Planning Department, \\ Shiraz University, Eram campus, Eram Boulevard, Shiraz, Iran \\ Email:djt2891@gmail.com \\ Farzane Dehghan Harati \\ Master of Educational Administration, Shiraz University, Shiraz, Iran \\ Email: dfarzane48@yahoo.com
}

\section{Doi:10.5901/mjss.2016.v7n6p61}

\begin{abstract}
This study was implemented to develop and validate a scale to assess organizational behavior foundations. Meanwhile, considering Hinkin's (1995) scale development stages and using Robbins and Judge's (2008-2009) framework, a survey was made containing 3 dimensions (individual, group and organizational), and 23 fundamental factors. The surveys were implemented among 250 male and female staff of an organization selected using simple stratified random sampling method. To develop the scale, first we identified a potential set of items for the constructs; next we assessed the psychometric properties of the scale by examining its components' relationship, using item-total correlations analysis. Results indicated that the scale was well-constructed, and had high reliability. Confirmatory factor analysis also was used to assess the measurement model and to infer the existence of construct's validity. Results demonstrated that the scale contains relatively good validity to explain the effects of organizational behavior foundations on staff behavior.
\end{abstract}

Keywords: Organizational Behavior, Organizational Behavior Foundations, Scale, Development, Validation

\section{Introduction}

As most studies indicate, organizational effectiveness is a significant concern for management labor in each organization (GitaKumari and Pradhan, 2014, p 46; Hossein, Ramezaninezhad, Yousefi, Sajjadi, Malekakhlagh, 2011; Chelladurai, 1987). Although Organizational effectiveness holds different meanings to different people, majority of authors approve that to understand organizational effectiveness various criteria ought to be measured and different organizational functions need to be evaluated (Hossein, etal. 2011, p 2). On the other hand, organizational effectiveness is the consequence of organizational performance and it can be measured through three different dimensions; employee performance, operational performance, and financial performance (Ketkar \& Sett, 2009, p 1 ). Accordingly, People and their performance within organization are key elements to achieve organization's effectiveness (Michie and West, 2004; Rogers \& Wright, 1998; as stated in GitaKumari and Pradhan, 2014, p 46). That is if employees perform better, it will contribute to overall effectiveness of the organization (Gita Kumari, Pradhan, 2014, p 46). The performance of the employees is a result of many factors including the behavior of them in the organization which is highly influential in the performance of the organization, too. As a matter of fact, the behavior of organization members will eventually result in its effectiveness or ineffectiveness through affecting the performance of the organization. It is the people and their working behavior not the physical capital that is seen as the most important predictor of organizational performance. Hence, the issue of people's behavior prediction and management has never been so important than it is today, and it requires the investigation of many variables (i.e. factors within the individual or the unit in which an individual is employed or the organization as a whole). These variables simultaneously affect the behavior of the people who in turn, play the optimum role in the performance and effectiveness of organizations.

Actually, Due to the importance of organizational behavior constructs in organization and management processes, hundreds of scales have been developed. These scales aimed to assess a lot of attitudes, perceptions, or opinions of organizational members and were to scrutinize hypothesized relationships of these elements with other constructs or behaviors (Hinkin, 1995, p 967). However, no comprehensive and complete scale has been developed to measure the contribution of entire prominent organizational behavior dimensions or factors in members' behavior and performance all 
at once. Hence, a comprehensive and integrated tool is required to investigate the factors mentioned in individual, group and organizational dimensions in order to measure and predict the impact of these factors on the behavior of members of the organization, and as a result offer further individual and organizational performance and effectiveness.

The results of this study could prepare a ground for analysis and evaluation of individuals' behavior within organization, and direct management behavior in order to lead the organization toward the desired effectiveness. This could be achieved through measuring the impact of each dimension or factor on members' behavior and performance.

\section{Literature Review}

\subsection{Organizational behavior and organizational behavior dimensions}

Most researchers and scholars (Moorhead \& Griffin, 2010; Robbins and Judge, 2008, 2009; Shermerhorn et al., 2002; Wagner and Hollenbeck, 2010; Mullins, 2002; Nelson and Quick, 2012; Olguin et al, 2009) defined organizational behavior as the study of human behavior in organizations, the study of individuals behavior facing with the organization and organization itself. But they have specifically studied and analyzed its factors in three dimensions: individual, group and organizational. Moreover, all the existing knowledge of organizational behavior scope considers issues which affect the behavior of individuals, and consequently organizational performance and effectiveness in these three dimensions (Delta, 2006; Robbins, 2005; Dubrin, 2007; Robbins \& Judge, 2008, 2009; McShane and Vonglino, 2010; Luthans, 2011). These dimensions act as important agents in forming individuals' behavior within organizations in conjunction with each other. In this regard, a great number of different scholars undertook various researches in the scope of organizational behavior dimensions (i.e. individual, group and organizational) and lots of scales were developed to assess these factors accordingly.

Among them the researches on individual behavior dimension includes the issues about individual behavior. Individual behavior is a result of individual's participation within organizations. This behavior consists of productivity as an indicator for the effectiveness of the individual's job and is measured based on services offered at first; but it also assesses performance which is much broader than efficiency and covers all related activities to job. Researches on group dimension focus on variables such as productivity and performance, too. But some unique features (including norms that guide the behavior of members of the group) which help determine the effectiveness of group behavior and create cohesion among group members are also considered. Studies on organizational dimension deal with features such as organizational function, effectiveness, communication with the environment, and employees' relationship. Therefore, the behavior of organization is examined based on them in order to return investment, increase growth rate or the organization's ability to survive, and their ability to satisfy external investors and regulators, and internal units and employees. Obviously, the impact of these dimensions is different depending on our position and level of analysis. Accordingly, so far a variety of models and frameworks have been proposed to analyze organizational behavior (Bear, 1980; Ivanko, 2012; Torkzadeh and Dehghan Harati, 2015). Development of these scales is indicative of the chief role of organizational behavior principles in individuals and organizations effectiveness and performance enhancement.

The results of these studies and a lot of others suggest that studying these dimensions: individual, Group or organizational, will lead to management and authorities understanding about personnel needs and expectations, and consequently will increase their job experience quality. As a matter of fact, considering these dimensions will result in individuals and organizations better effectiveness and performance in the long run. However, the impacts of these dimensions have not been investigated coherently and simultaneously in an organization because of the loss of a comprehensive instrument to accomplish it. This study, however, attempted to achieve this goal. Table 1 shows some of these studies.

Table 1: Examples of earlier research

\begin{tabular}{|l|l|}
\hline Dimensions & Researchers \\
\hline & Ejei,; Weisani, Siadat, Khezriazar (2011), Baghani \& Dehghani (2011), Yusefi, Ghasemi and firooznia (2009), Al- \\
& Rfou \& Trawneh (2009) \\
& Zarifi, Yusefi \& sadeghi (2012), Salami, Gheysari \& Abbasi (2012), Nasiri etal (2012) \\
& Andotra \& Harlin(2012) Noori etal (2012), Balassiano \& Salles(2012), Alen (2011) \\
Individual & Habibi, etal,(2013), Asif Khan (2012) \\
& Esmaili and Husseini (2012), Palombo, Miler, Shalin, Steel-Johnson (2005) \\
& Azim-Zadeh, Khabiri and Asadi (2009), Macboy and Jacqueline (1974), the retired association of America (1995) \\
& Kamalian and Fazel (2011), Sobhi Gharamaleki (2012), Thomas Joy (2011), Gundal and Hussain (2013) \\
& Nejat Koohestani and Rezaei (2011), Kajbaf, Molavi, shirazi(2004), Malik, Danish and Osman (2011) \\
& Sheikh Sary and Ismaili Far (2010), Awadh and Ismail (2012)
\end{tabular}




\begin{tabular}{|l|l|}
\hline \multirow{5}{*}{ Group } & $\begin{array}{l}\text { Torkzadeh and Jafari (2011), Nazam \& pourshafee(2012), Antonaksyand Hause (2002), Peterson et al. (2003) } \\
\text { Doaee and Rajabi pour (2011), Holten \& Rosenkranz (2009) } \\
\text { Dargahi(2012), Galinsky (2003) } \\
\text { Muqbil and Hadavi nezhad (2009), Fereydooni (2013), Ollah et al(2011) } \\
\text { Nasiri pour A. Riahi and Afzal (2009), Williams (2011) } \\
\text { Allameh etal(2012), Nahapiet and Ghoshal (1998), Pherson etal (2013) } \\
\text { Choi, Sung and Kim (2010), Anwar etal (2012) }\end{array}$ \\
\hline \multirow{5}{*}{ Organizational } \\
& $\begin{array}{l}\text { Nasiri Pour , etal (2009), Salmani nezhad, etal (2012), Cameron and Quinn (2006) } \\
\text { Khalil Zadeh, Mostafa Pour Ravanbakhsh (2013), Volf \& Rod (1995), Chase(2008); Pearlson \& Saunders (2006) } \\
\text { Torkzadeh and Mohtaram(2014), Torkzadeh and Zeinali (2012), Hoy and Switland (2001), Ogbonna (2003), } \\
\text { Nasurdin et al (2006) } \\
\text { Vaziri and Shirzadi (2012), Khorana (2012), Balakrishnan (2013), Holloway (2012) } \\
\text { Mojibi and Milani(2011), Ferholm (2009), Baker and Torodis (2010) } \\
\text { Eerabi (2000), Eerabi \& Haghighi (2010), Philippe (2004) } \\
\text { Seyedi and Sarlab (2012), Espiglar, Guise and Hutgm (2012) }\end{array}$ \\
\hline
\end{tabular}

\subsection{Organizational behavior factors}

In particular, different scholars (Robbins and Judge, 2008, 2009; Wagner and Hollenbeck, 2010; Dubrin, 2007; Shermerhorn et al., 2002, 2003; Mullins, 2010, Morehead and Griffin, 2010; Luthans, 2011) and a host of others recognized following factors for individual, group and organizational dimensions.

Individual factors: biographic features, personality, intelligence, abilities, values, attitudes, perception, learning and motivation of each individual.

Group factors: group features, leadership, communication, power, politics and conflict, and organizational groups' social capital.

Organizational factors: strategy, structure, technology and job design, culture, climate and environment. The definitions of factors and indicators applied in this study are summarized in table 2.

Table 2: Definitions, factors and indicators of organizational behavior foundations scale

\begin{tabular}{|c|c|c|c|}
\hline DIMENSIONS & FACTORS & DEFINITION & INDICATORS \\
\hline \multirow{9}{*}{ INDIVIDUAL } & $\begin{array}{l}\text { BIOGRAPHIC } \\
\text { CHARACTERISTICS }\end{array}$ & $\begin{array}{l}\text { Include some features that are easily identifiable in } \\
\text { people such as age, gender, marital status, (Robbins } \\
\text { and Judge, 2009; Shermerhorn et al., 2003), } \\
\text { employment status, social origin (Rollinson \& Broadfield, } \\
\text { 2002). }\end{array}$ & Age, gender, marital status, employment status, social origin \\
\hline & INTELLIGENCE & $\begin{array}{l}\text { The ability to think abstractly, learn from experience, } \\
\text { solve problems through insight, adapting to new } \\
\text { situations, focus and persistence in applying skills to } \\
\text { achieve a goal (DeYoung, Sternberg, Kaufman, 2011). }\end{array}$ & $\begin{array}{l}\text { Thinking, learning from experience, the ability to analyze and } \\
\text { solve problems through insight, adaptation }\end{array}$ \\
\hline & ABILITY & $\begin{array}{l}\text { Person's capacity to perform a variety of tasks or work } \\
\text { with mentally, physically, and thinking skills and abilities } \\
\text { must be fit with the person's job. (Robbins and Judge, } \\
\text { 2009) }\end{array}$ & $\begin{array}{l}\text { Mental ability (numerical aptitude, verbal comprehension, } \\
\text { perceptual speed, reasoning, etc.), physical ability (strength, } \\
\text { flexibility, coordination, endurance) thinking skills (analytical, } \\
\text { numerical, reflection, visual, creative, and critical. ..), work and } \\
\text { ability fitness }\end{array}$ \\
\hline & PERSONALITY & $\begin{array}{l}\text { Durable and unique set of features (Schultz And } \\
\text { Schultz, 2008; Meyer, 2007; Larsen \& Buss, 2005), } \\
\text { which may change in response to different situations } \\
\text { (Schultz and Schultz, 2008). }\end{array}$ & $\begin{array}{l}\text { Extroversion (Expressed emotion, being social, extroverted) } \\
\text { Consensus (gentle-hearted, reliable, cooperative) } \\
\text { Conscientiousness (responsible, reliable, durable) } \\
\text { Emotional stability (non-anxious, comfortable, calm) } \\
\text { Open-mindedness (Fantasy, curiosity, broad mindedness) }\end{array}$ \\
\hline & BELIEF SYSTEM & $\begin{array}{l}\text { A mix of ideologies, worldviews, values as a basis for } \\
\text { affairs 'assessment (Ross, 1980; Retz, 2001; Walsh, } \\
\text { 2003; Wechsler, 2006; Parhizgar, 2003). }\end{array}$ & Ideologies, worldviews, and personal values \\
\hline & ATTITUDES & $\begin{array}{l}\text { Favorable or unfavorable interpretations of the } \\
\text { environment that allows the individual to express a } \\
\text { positive or negative reaction (Shermerhorn et al., 2003; } \\
\text { Robbins, 2009) }\end{array}$ & $\begin{array}{l}\text { Cognition, emotion, action, dissonance, organizational } \\
\text { commitment, job satisfaction }\end{array}$ \\
\hline & PERCEPTION & $\begin{array}{l}\text { the set of processes by which a person notifies } \\
\text { environmental stimuli and organizes and interprets } \\
\text { them(Luthans, 1992; Robbins and Judge, 2008; } \\
\text { Moorhead and Griffin, 2010; Shermerhorn et al., 2003) }\end{array}$ & $\begin{array}{l}\text { Stimuli, organize events based on experience, individual } \\
\text { interpretation of events, and individual experiences of the } \\
\text { organization's past events or dealings. }\end{array}$ \\
\hline & LEARNING & $\begin{array}{l}\text { a complex cognitive process that includes a permanent } \\
\text { change in knowledge, attitude or behavior as a result of } \\
\text { his experience during his interaction with the } \\
\text { environment (Hill, 2002; Hoy and Miskel, 2013) }\end{array}$ & Knowledge, skill, attitude, experience \\
\hline & MOTIVATION & $\begin{array}{l}\text { The internal state (Guey et al., 2010; Lai, 2011) that } \\
\text { stimulates, steers and maintains the behavior (Hoy and } \\
\text { Miskel, 2013) }\end{array}$ & Needs, beliefs, goals \\
\hline
\end{tabular}




\begin{tabular}{|c|c|c|c|}
\hline \multirow{7}{*}{ GROUP } & GROUP FEATURES & $\begin{array}{l}\text { Features that shape the behavior of its members. And } \\
\text { make the contribution of individual behavior and group } \\
\text { performance predictable in the future. (Robbins and } \\
\text { Judge, } 2008 \text { and 2009) }\end{array}$ & $\begin{array}{l}\text { Roles, group norms, group status, group size, level of group } \\
\text { cohesion, group functions (security, status, esteem, } \\
\text { independence, power, providing objective), composition } \\
\text { (heterogeneity) interaction, decision-making and collective } \\
\text { thinking, single action and indifference, group's culture and } \\
\text { environment }\end{array}$ \\
\hline & LEADERSHIP & $\begin{array}{l}\text { The ability to influence a person or group on a track to } \\
\text { achieve a set of goals (Robbins and Judge, 2008, } \\
\text { Mullins, 2002) }\end{array}$ & $\begin{array}{l}\text { Human communication, goal setting, creating individual } \\
\text { motivation and direction }\end{array}$ \\
\hline & COMMUNICATIONS & $\begin{array}{l}\text { A process by which individuals, groups and organization } \\
\text { are linked together using the signs and verbal messages } \\
\text { in formal and informal contexts. And will create the } \\
\text { meaningful relationships between them. (Luthans, 1992, } \\
\text { Mac Crosky and Mac Crosky, 2005; Lunenburg and } \\
\text { Ornstein, 2012). }\end{array}$ & $\begin{array}{l}\text { Process (sender, message, receiver, feedback) } \\
\text { Communication directions (top-down, bottom-up, horizontal) } \\
\text { Communication barriers (filtering, personality, gender, } \\
\text { emotions, words, body language) } \\
\text { Formal and informal communication networks (rumors) }\end{array}$ \\
\hline & POWER & $\begin{array}{l}\text { The ability to influence corporate decision making } \\
\text { processes and influencing the organization's activities } \\
\text { (Tolbert and Hall, 2009) }\end{array}$ & $\begin{array}{l}\text { Expertise, legitimacy, authority, discipline, coercion, } \\
\text { information, culture, environmental domination, ethics }\end{array}$ \\
\hline & POLITICS & $\begin{array}{l}\text { A series of activities outside the official roles of } \\
\text { members to acquire, or to increase the use of power and } \\
\text { other resources within organization. (Gary and Ariss, } \\
\text { 1985; Robbins and Judge, 2008; Hoy and Miskel, 2013) }\end{array}$ & $\begin{array}{l}\text { Political tactics (flattery, networking, data management, } \\
\text { managing interpretations and perceptions, coalition building, } \\
\text { and behaving others as scapegoats) } \\
\text { Political games (insurgency, creating power games, power- } \\
\text { driven games, expert power, power to rule... ) } \\
\text { Power games (leaving the organization, protest, loyalty to } \\
\text { organization) }\end{array}$ \\
\hline & CONFLICT & $\begin{array}{l}\text { Perceived incompatibilities or opposing views among } \\
\text { groups that allows an individual or a group, individual } \\
\text { see other individuals and groups as potential obstacles } \\
\text { to the realization of its goals. (Williams, 2011; } \\
\text { Rezayian,2004) }\end{array}$ & $\begin{array}{l}\text { Cognitive conflict (task, group precautions, resources) } \\
\text { emotional conflicts (social-emotional issues, group values, } \\
\text { group identity), interpersonal conflict (conflict of roles and } \\
\text { personality) intergroup conflict (vertical Conflict, horizontal } \\
\text { conflict, line and staff...) fundamental conflict (conflict of } \\
\text { purpose, procedure, and cognition), emotional (feelings such as } \\
\text { anger, distrust, etc.). }\end{array}$ \\
\hline & SOCIAL CAPITAL & $\begin{array}{l}\text { Set of norms, networks, and social trust run in a system } \\
\text { (WoolCock, 2001; Schuler, 2001; Woods, 2008) }\end{array}$ & Norms, networks, trust \\
\hline \multirow{7}{*}{ ORGANIZATIONAL } & $\begin{array}{l}\text { ORGANIZATIONAL } \\
\text { STRUCTURE }\end{array}$ & $\begin{array}{l}\text { Formal pattern of interactions and coordination between } \\
\text { individuals, with different jobs within groups and } \\
\text { organizations to achieve organizational goals and to } \\
\text { Detect limits and boundaries of individuals and groups } \\
\text { responsibilities in the use of resources. (Bartol et al., } \\
\text { 2001, Mullins, 2002; Jones, 2012; Hoy and Miskel, } \\
\text { 2013) }\end{array}$ & $\begin{array}{l}\text { Formalization, centralization, process, context, enabling } \\
\text { structure, hindering structure }\end{array}$ \\
\hline & STRATEGY & $\begin{array}{l}\text { Outline the precautions and required actions } \\
\text { (Shermerhorn et al., 2003) to achieve substantial goals } \\
\text { of an organization through determining goals, adopting } \\
\text { procedures and resource allocation (Robbins, 2001) }\end{array}$ & $\begin{array}{l}\text { Organization precautions } \\
\text { Corporate Actions } \\
\text { Organization desirables } \\
\text { Goal -setting } \\
\text { Procedure Selection } \\
\text { Allocation of resources } \\
\end{array}$ \\
\hline & TECHNOLOGY & $\begin{array}{l}\text { A complex combination of hardware, software, brain } \\
\text { application, human resources and organizing and } \\
\text { management within an organization (Jafarnejad, 1999) } \\
\text { by which human capability is extended convert inputs } \\
\text { into outputs in an organization(Daft, 1999) }\end{array}$ & $\begin{array}{l}\text { Hardware (physical equipment) } \\
\text { Software (application of hardware) } \\
\text { Brain application (the reasons for the use of hardware) } \\
\text { Human resources (talent required for using software and } \\
\text { hardware) } \\
\text { Management and organization ( economic and social and } \\
\text { administrative arrangements, and mechanisms) }\end{array}$ \\
\hline & JOB DESIGN & $\begin{array}{l}\text { Building specialized content, methods and job } \\
\text { relationships to fulfill individuals' personal and social } \\
\text { needs (trade association of the UK, 2008) including; } \\
\text { creating responsibility for the consequences, creating } \\
\text { meaningful jobs, and knowledge creation through the } \\
\text { outcomes of the activities (Hackman \& Oldham, 1980) }\end{array}$ & $\begin{array}{l}\text { Skill variety, task identity, task significance, autonomy, } \\
\text { feedback }\end{array}$ \\
\hline & $\begin{array}{l}\text { ORGANIZATIONAL } \\
\text { CULTURE }\end{array}$ & $\begin{array}{l}\text { A System of common perceptions of organizational } \\
\text { members toward the organization which separates } \\
\text { organizations from one another (Schein, 1990, 2004, } \\
\text { Lunenburg and Ornstein , 2012; Desson \& Clouthier, } \\
\text { 2010) }\end{array}$ & $\begin{array}{l}\text { Innovation, attention to detail, attention to consequences, pay } \\
\text { attention to people, pay attention to teamwork, racing, stability }\end{array}$ \\
\hline & $\begin{array}{l}\text { ORGANIZATIONAL } \\
\text { CLIMATE }\end{array}$ & $\begin{array}{l}\text { Set of organizational internal characteristics (Hoy and } \\
\text { Miskel, 2013), and relatively durable quality of the } \\
\text { organizational environment (Spirol, 2008) that influences } \\
\text { the behavior of organizational members and determines } \\
\text { their feelings toward the organization. }\end{array}$ & Credibility, respect, justice, pride, friendship \\
\hline & ENVIRONMENT & $\begin{array}{l}\text { Set of factors that are associated with the target system } \\
\text { and are effective on the system's goal and performance, } \\
\text { but system has little control on them (Daft, 2001; } \\
\text { Robbins, 1990; Torkzadeh, 2008). }\end{array}$ & Cultural, economic, social, political, legal \\
\hline
\end{tabular}




\section{Methodology}

\subsection{Population and sampling size}

The population consisted of all staff of an organization (1,100 people). Using simple stratified random sampling method and with regard to Morgan table 285 individuals were selected as the sample. Surveys were distributed among them and response rate was \% 87.7 (250 individuals). Table 3 illustrates the demographic characteristics of the study participants based on their gender.

Table 3: Number and percent of the participants based on their gender demographic characteristics

\begin{tabular}{|c|c|c|c|}
\hline \multicolumn{2}{|c|}{ Demographic characteristics } & NO & Percent \\
\hline \multirow{2}{*}{ Gender } & male & 134 & 53.6 \\
\cline { 2 - 4 } & female & 116 & 46.4 \\
\hline Total & \multicolumn{3}{|c|}{250} \\
\hline
\end{tabular}

\subsection{Research design and steps}

The overall goal of this study was to develop and validate a scale to assess the foundations of organizational behavior. To do so, Hinkin's (1995) scale development stages were considered. Given to Hinkin's stages, to formulate the model a wide review was carried out on the existing frameworks and finally possible constructs were identified considering Robbins and Judge's (2008) framework as a rather complete framework.

For scale's item generation and for data collection_ in a deductive manner, theoretical and research literature of organizational behavior dimensions and the factors underlying them were studied thoroughly: And given to this framework, organizational behavior foundations were established as three dimensions; individuals, group and organizational. Individual dimension embraces nine factors: Biographic characteristics, personality, intelligence, abilities, values, attitudes, perception, learning and motivation. Group dimension consists of seven factors: characteristics of group, leadership, communication, power, politics and conflict, and social capital. And organizational dimension consists of seven factors: strategy, organizational structure, technology, job design, organizational culture, organizational climate, and environment. For Scale Development at first, to design the study we identified a potential set of items for the constructs under consideration and examined their correlation with each other. Second, for scale construction we used item-total correlations to form the scale. Third, Cronbach's Alpha was used for reliability assessment and finally the scale was developed in a five-point Likert type. The aim of all the previous stages in the scale development process was to create measures that prove validity and reliability. Finally, to assume the presence of construct validity, confirmatory factor analysis was used.

Table 4: Distribution of items of the scale in terms of dimensions and factors of organizational behavior foundations

\begin{tabular}{|c|c|c|}
\hline Dimensions & Factors & No Of Items \\
\hline \multirow{9}{*}{ Individual } & Biographic Characteristics & $1,2,3,4,5$, \\
\hline & Intelligence & $6,7,8,9$ \\
\hline & Ability & $10,11,12,13,14$ \\
\hline & Personality & $15,16,17,18,19$, \\
\hline & Belief System & $20,21,22$ \\
\hline & Attitudes & $23,24,25,26$ \\
\hline & Perception & $27,28,29,30$ \\
\hline & Learning & $31,32,33,34$ \\
\hline & Motivation & $35,36,37,38$ \\
\hline \multirow{7}{*}{ Group } & Group Features & $39,40,41,42,43$ \\
\hline & Leadership & $44,45,46$, \\
\hline & Communications & $47,48,49,50$ \\
\hline & Power & $51,52,53,54,55$ \\
\hline & Politics & $56,57,58,59$, \\
\hline & Conflict & $60,61,62,63,64$ \\
\hline & Social Capital & $65,66,67$ \\
\hline
\end{tabular}




\begin{tabular}{|c|c|c|}
\hline \multirow{4}{*}{ Organizational } & Organizational Structure & $\mathbf{6 8 , 6 9 , 7 0 , 7 1 , 7 2}$ \\
\cline { 2 - 3 } & Strategy & $\mathbf{7 3 , 7 4 , 7 5 , 7 6}$ \\
\cline { 2 - 3 } & Technology & $\mathbf{7 7 , 7 8 , 7 9}$ \\
\cline { 2 - 3 } & Job Design & $\mathbf{8 0 , 8 1 , 8 2 , 8 3}$ \\
\cline { 2 - 3 } & Organizational Culture & $\mathbf{8 4 , 8 5 , 8 6 , 8 7}$ \\
\cline { 2 - 3 } & Environment & $\mathbf{8 8 , 8 9 , 9 0 , 9 1}$ \\
\cline { 2 - 3 } & Organizational Climate & $\mathbf{9 2 , 9 3 , 9 4 , 9 5 ,}$ \\
\hline
\end{tabular}

\section{Findings}

\subsection{Validity and reliability of the scale of organizational behavior foundations: Items-correlation analysis and Cronbach's alpha}

As shown in Table 5, validity evaluation of the scale dimensions and factors using item analysis showed that each dimension and factor of this scale has a relatively high validity. Cronbach's alpha was used in order to assess the reliability of the scale dimensions and factors, and results demonstrated that each of the dimensions and factors has a relatively high reliability, as well.

Table 5: Internal Correlation coefficients range and Cronbach's alpha of dimensions and factors of organizational behavior foundations scale

\begin{tabular}{|c|c|c|c|}
\hline Dimensions & Correlation Coefficient & Sig. & Cronbach's Alpha \\
\hline Individual & $0.41-0.88$ & $0.01-0.0001$ & 0.78 \\
\hline Group & $0.47-0.83$ & $0.001-0.0001$ & 0.89 \\
\hline Organizational & $0.57-0.85$ & $0.001-0.0001$ & 0.86 \\
\hline Factors & Correlation coefficient & sig. & Cronbach's Alpha \\
\hline Biographic characteristics & $0.46-0.81$ & $0.009-0.0001$ & 0.65 \\
\hline intelligence & $0.76-0.84$ & 0.0001 & 0.86 \\
\hline ability & $0.59-0.87$ & $0.001-0.0001$ & 0.80 \\
\hline personality & $0.51-0.75$ & $0.001-0.0001$ & 0.72 \\
\hline Belief system & $0.58-0.87$ & $0.001-0.0001$ & 0.65 \\
\hline attitudes & $0.38-0.83$ & $0.03-0.0001$ & 0.69 \\
\hline perception & $0.77-0.89$ & 0.0001 & 0.89 \\
\hline learning & $0.76-0.86$ & 0.0001 & 0.81 \\
\hline motivation & $0.65-0.81$ & 0.0001 & 0.71 \\
\hline Group features & $0.41-0.88$ & $0.02-0.0001$ & 0.65 \\
\hline Leadership & $0.91-0.93$ & 0.0001 & 0.93 \\
\hline communications & $0.37-0.77$ & $0.04-0.0001$ & 0.70 \\
\hline power & $0.62-0.86$ & 0.0001 & 0.84 \\
\hline politics & $0.69-0.88$ & 0.0001 & 0.81 \\
\hline conflict & $0.75-0.85$ & 0.0001 & 0.87 \\
\hline Social capital & $0.68-0.86$ & 0.0001 & 0.74 \\
\hline Organizational structure & $0.64-0.86$ & 0.0001 & 0.85 \\
\hline strategy & $0.60-0.81$ & 0.0001 & 0.79 \\
\hline technology & $0.73-0.89$ & 0.0001 & 0.76 \\
\hline Job design & $0.62-0.84$ & 0.0001 & 0.72 \\
\hline Organizational culture & $0.72-0.87$ & 0.0001 & 0.90 \\
\hline Environment & $0.40-0.87$ & $0.02-0.0001$ & 0.87 \\
\hline Organizational climate & $0.87-0.90$ & 0.0001 & 0.89 \\
\hline & & & \\
\hline & & & \\
\hline
\end{tabular}

\subsection{Confirmatory factor analysis}

Confirmatory factor analysis was applied to examine the model structure. For this purpose, three-factor model of organizational behavior foundations scale was drawn by Amos and tested later. First, we examined the validity of each dimension and then the total model. The results of this analysis indicated that each of the three dimensions and their factors have a high reliability to explain the foundations of organizational behavior. Figure 1 shows the 3 -factor model and 
confirmatory factor structure of the scale along with factorial loads.

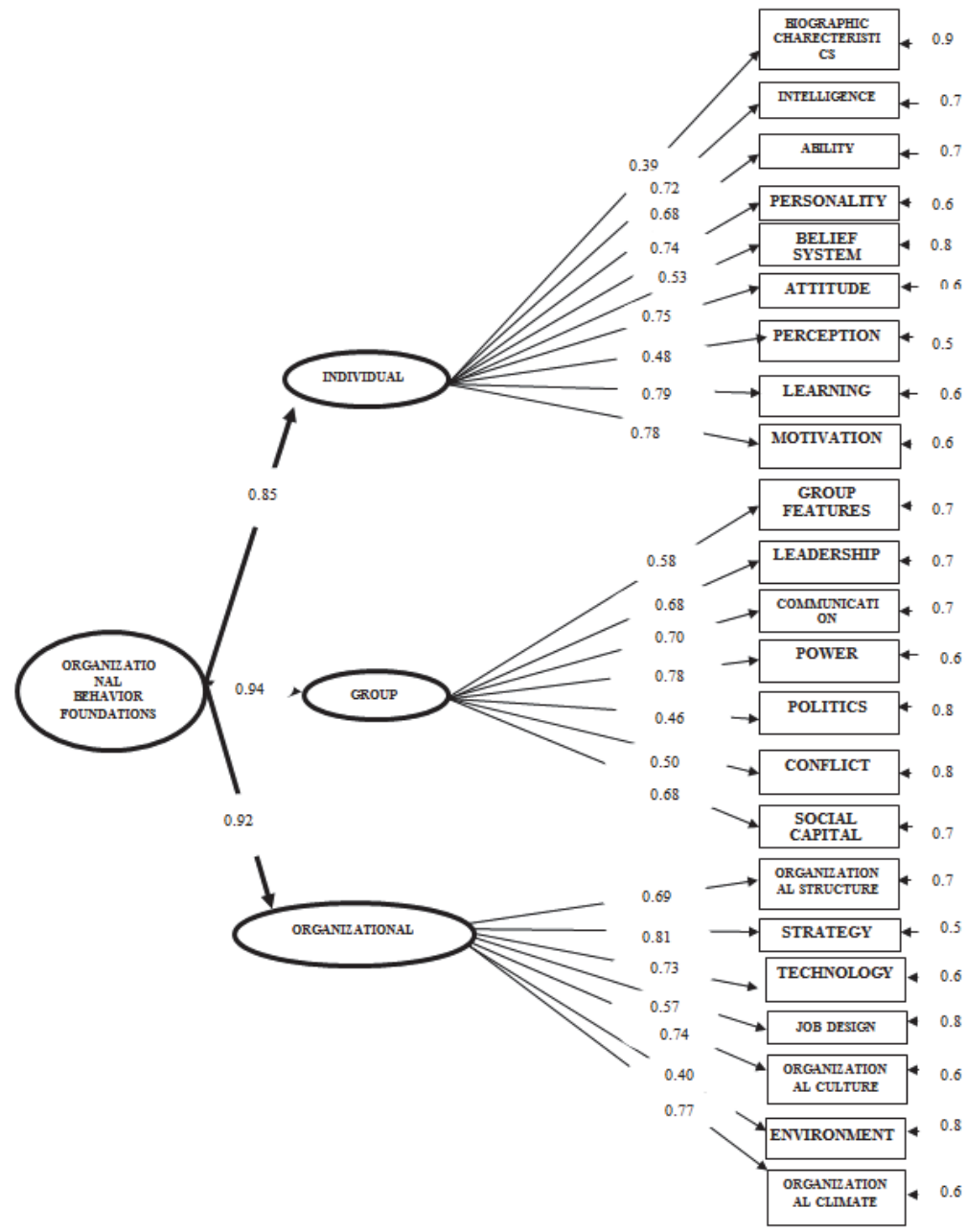

Figure 1. Confirmatory factor analysis structure: 3 - Factor model

\section{Discussion and Conclusion}

This study aimed to develop and validate a scale to assess organizational behavior foundations. According to Hinkin (1995), in order to formulate and validate a scale two points should be considered; first, the components and their relevance and second, total model's validation. For the first purpose, the results of item-generation and scale development, item total construction and reliability assessment were satisfactory and showed that the scale had a high validity and reliability. For the second purpose, the results of confirmatory factor analysis showed high construct validity between the dimensions and items and total model.

Corporations are striving to achieve sustainable and efficient competitive advantages within their environment. They do it through using different resources and performing a lot of activities. One of them is human resources and the processes for managing them. Management literature is full of statements from theorists that "people are our most important asset" and "people make all the difference". Moreover, there is a growing body of literature supporting that the effectiveness with which corporations manage, develop, motivate, involve, and engage in environment is a key 
dynamic of how well those corporations perform in different aspects; especially human resource management. This, in turn, creates a certain value for organizations to learn about their components, specially their members' behavior (March 1999; Shermerhorn et al., 2002; Luthans, 2011). In general, the impact of individual, group and organizational elements within the organization on the behavior of people and improving their performance and, consequently, individual and organizational effectiveness is unquestionable and could not be ignored (Robbins and Judge, 2008). That is why, a gap was felt to develop a scale in order to facilitate understanding and identifying organizational behavior foundations and factors' impact on individual's working behavior and their performance. In this study we tried to fulfill this goal. The aforementioned scale is presented at the end of this article.

\section{References}

Abbaspour, A. (2003) Advanced Human Resource Management (Approaches, Processes and Functions). Tehran: SAMT.

Alen, S. (2011) . The Effect of A Market Orientation And Employee Learning Orientation On Organizational Commitment. Alto University School Of Economics, Department Of Marketing And Management. Marketing master's thesis

Allameh, S. M.; Harooni, A.; Bovandey, F. (2012). Investigating the Relationship between Social Capital And Knowledge Transfer Within An Organization. American Journal of Scientific Research. 74, 14-24.

Allameh, S. M.; Shahriari, M.; Mansoori, H. (2012). Investigating Employee's Attitude toward Organization, Organizational Climate and Employee's Engagement as Antecedents of Organizational Citizenship Behavior. Australian Journal of Basic and Applied Sciences. 6, 8, 384-393.

Al-Rfou, A., and Trawneh, Kh. (2009). Achieve Competitive Advantage Through Job Motivation. Journal of Social Sciences, 20(2): 105107.

Andotra, N \& Harleen, Ms. (2012). Job Attitude To Job Involvement - A Review Of Indian Employees prof. IOSR Journal Of Business And Management (IOSRJBM) Volume 2, Issue 4, pp 01-09. www.iosrjournals.org

Asif Khan, M. (2012). Ethical Values and Work Related Outcomes: An Empirical Study Of Pakistani Organizations. African Journal of Business Management. Vol. 6(11), Pp. 3977-3987.

Awadh, A. M. \& Saad, A. M. (2012). A Conceptual Study on Effect of Personality Traits and Self-Efficacy in Saudi Arabia Organizations. Asian Journal of Business and Management Sciences. 1, 11, 109-115.

Baghani, M. and Dehghani Nishaboori, M. (2012). A Study Of Academic Motivation, Self-Efficacy And Study Approaches Effect On Academic Achievement. Ferdosi University Of Mashhad, The First National Conference Of Cognitive Science In Education .Confbank.Um.Ac.Ir/Modules/Conference

Balakrishnan, K. (2013). An Integration Of Organisation Climate Research. International Conference On Technology And Business Management.

Balassiano, M. \& Salles, D. (2012). Perceptions Of Equality And Justice And Their Implications On Affective Organizational Commitment: A Confirmatory Study In A Teaching And Search Institute. Brazilian Administration Review. 9, 3, 268-286.

Chase, N. (2008). An Exploration Of Culture Of Information Technology: Focus On Unrelenting Change. Journal of Information, Information Technology and Organizations.3, 135-150.

Chelladurai, P. (1987). Multidimensionality and Multiple Perspectives of Organizational Effectiveness. Journal of Sport Management, 1, $37-47$

Choi, J.N \& Sung, S.Y \& Kim, M.U. (2010). How Do Groups React To Unexpected Threats? Crisis Management In Organizational Teams. Social Behavior And Technology. 38, 6, 805-828.

Dubrin, A. (2007). Fundamentals Of Organizational Behavior. OH: Thomson South Western.

Ejei, J.; Weisani, M.; Siadat, S.; Khezriazar, H. (2011). The Role Of Academic Motivation And Learning Strategies In Statistics Anxiety: Testing A Causal Model. Journal Of Psychology, 15,110-128

Esmaili, B.; Hosseini, H. (2012). A Study Of The Relationship Between Skills And Abilities And Management Roles. Journal Of New Approach In The Educational Administration. Islamic Azad University Of Marvdasht. Volume3, No. 1, Pp. 103-120.

Fairholm, M. R. (2009). Leadership And Organizational Strategy. The Innovation Journal: The Public Sector Innovation Journal, Scholarly-Style Papers, 14(1), Article3. http://www.innovation.cc/volumes-issues/vol14-no1.htm

Gita Kumari, I. And Pradhan, R.K. (2014). Human Resource Flexibility And Organizational Effectiveness: Role Of Organizational Citizenship Behavior And Employee Intent To Stay. International Journal Of Business And Management Invention. Volume 3 Issue 11. PP.43-51.

Gondal, H. And Husain,T. (2013). Comparative Study Of Intelligence Quotient And Emotional Intelligence: Effect On Employees' Performance. Asian Journal Of Business Management 5(1): 153-162, / A

Gray, B., \& Ariss, S. (1985), "Politics and strategic change across organizational life cycles", Academy of Management Review, vol.10, pp.707-723.P 707.

Habibi, M.; Khodabakhshi Kolaee, A. ; Rashidi Hor, J.; Gharibvand, H.R. (2013). The Relationship Between Value System And The Education Personnel's Organizational Commitment Of Izeh City By The Year 2010. Quarterly Journal Of Career \& Organizational Counseling. Vol 5, No, 14, Pp 46- 65.

Heath, Ch. \& Sitkin, S. (2001). Big-B Versus Big-O: What Is Organizational Behavior? Journal of Organizational Behavior.22, 43-58.

Hinkin, T.R. (1995). A Review of Scale Development Practice in the Study of Organizations. Journal of Management. Vol. 21, No. 5,967- 
988.

Holloway, J. B. (2012). Leadership Behavior and Organizational Climate: An Empirical Study In A Nonprofit Organization. Emerging Leadership Journals. 5, 1, 9-35.

Holten, R. \& Rosenkranz, Ch. (2008). Communication in Organizations: The Heart Of Information Systems .Sprouts: Working Papers on Information Systems, 8(29). http://aisle.aisnet.org//sprouts_all

Hossein, E.; Ramezanineghad, R.; Yousefi, B., Sajjadi, S. N.; Malekakhlagh, E. (2011). Compressive Review of Organizational Effectiveness In Sport. International Journal of Sport Management. Vol. 7, Number 1.Pp 5-21.

Kamalian, A. R. And Fazel, A. (2011). Exploring the Relationship between Students' Emotional Intelligence And Entrepreneurship (Case Study: University Of Sistan And Baluchistan). Entrepreneurship Development. Issue 3, No. 11, Pp. 127-147.

Ketkar, S., \& Sett, P. K. (2009). HR flexibility and firm performance: Analysis of multi-level causal Model. The International Journal of Human Resource Management, 20 (5), 1009-1038.

Khorana, V. (2013). Organizational Climate and Job Satisfaction Of Teachers In Schools. Research Paper, International Indexed \& Refereed Research Journal. VOL - IV , ISSUE 40.

Luthans, F. (2011). Organizational Behavior: An Evidence Based Approach, 12 ${ }^{\text {th }}$ Ed. Mcgraw-Hill.

Mcshane, S. L., \& Von Glinow, M. (2010). Organizational Behavior, 5th Ed. Burrridge, Illinois: Mcgraw Hill.

Michie, S. And West, M.A. (2004). People And Performance: An Evidence Based Framework Applied To Health Service Organizations. International Journal Of Management Reviews .Volume 5/6 Issue 2 Pp. 91-111.

Mitchell, T. R. (1979). Organizational Behavior. Annual Review Of Psychology. 30, 243-281.

Mojibi, T. And Milani, M. (2011). The Relationship between Organizational Strategy And Structure Inthe Electricity Distribution Companies Of Tehran Districts. Journal Of Management, Vol. 8, No. 22. Pp 14-23.

Moorhead, G. \& Griffin, R. W. (2010). Organizational Behavior: Managing People And Organizations, 9th Edition. South Western, Cengage Learning.

Mullins, L. J. (2010). Management And Organizational Behavior, 9th Edition. Prentice Hall

Nahapiet, J. \& Ghoshal, S. (1998). Social Capital, Intellectual Capital, and the Organizational Advantage. Academy Of Management. The Academy Of Management Review. 23, 2, 242.

Nasiri Pour, A,; Reesi, P.; Hedayati, P. (2009). Relationship Between Organizational Culture And Employee Productivity In The Public Hospitals Of Iran University Of Medical Sciences. Journal Of Health Management, Volume 12, Issue 35, Pp. 17-25.

Nasiri, A.A.; Riahi, L. Afzal, E. (2009). Communications System And Its Relationship To Organizational Conflicts In The Tehran Hospital Complex Of Rasoul Akram. Journal Of Management Studies, No. 83, Pp. 55-64.

Nejat, N. Koohestani, HR, Rezaei, K. (2011). Investigation Of The Concept Mapping Effect On Nursing Students' Learning Approaches. Journal Of Nursing And Midwifery, Tehran University Of Medical Sciences (Life). Volume 17, No. 2, Pp. 22-31.

Noori, A.; Sabahi, P.; Salahian, A.; Samim, R. (2012). The Relationship Between Job Satisfaction And Perceived Organizational Justice And Organizational Citizenship Behavior: The Demographic Variables. Contemporary Psychology. 7.1, Pp. 49-60.

Olguin, D. Gloor, P. Pentland, A. (2009). Capturing Individual And Group Behavior With Wearable Sensors. Spring Symposium On Human Behavior Modeling, Stanford.

Pearlson, K. E. \& Saunders, C. S. (2006). Managing \& Using Information Systems: A Strategic Approach, 3rd Ed. Danvers, MA: John Wiley \& Sons, Inc.

Robbins S.P. \& Judge T. (2009a). Organizational Behavior, 13th Edition. Pearson International Edition.

Robbins, S. \& Judge, T. A. (2008). Essentials Of Organizational Behavior.9th Edition. Prentice Hall Inc., Newjersy.

Robbins, S. P. (1990). Organizational Theory. 3rd Ed .P 205.

Robbins, S. P. (2005). Organizational Behavior, Eleventh Edition, Prentice- Hall Of India.

Robbins, S.P \& Judge, T. (2009b). Organizational Behavior, 13th Edition. Pearson International Edition.

Rogers, E.W., \& Wright, P.M. (1998). Measuring Organizational Performance In Strategic Human Resource Management: Problems, Prospects, And Performance Information Markets. Human Resource Management Review, 8, 311 - 331.

Shenhav, Y. W. Shrum, And Alon, S. (1994). Goodness Concepts In The Study Of Organizations: A Longitudinal Survey Of Four Leading Journals. Organization Studies, 15, 5, 753-776.

Seyedi, A. And Sarlab, Z. (2012). Women's Job Design: An Influential Factor For Organizations' Efficiency. Forough Tadbir. No 20, Pp. $55-62$

Sobhi Gharamaleki, N. (2012). Predicting Academic Achievement Motivation Based On Emotional Intelligence Of Students. Journal Of School Psychology. Period 1, No 3, Pp. 49-62.

Torkzadeh, J. and Dehghan Harati, F. (2015). A Comparative Analysis of Staff Organizational Behavior Foundations (A Case Study of Shiraz University). Asian Journal of Research in Social Sciences and Humanities. Vol. 5, No. 3, pp. 239-261.

Vaziri, M.; and Shirzadi Esfahani, H. (2012). Relationship between Organizational Climate And Joy And Vitality In The Faculty Members Of Al Zahra University. New Pedagogy Thoughts Journal, College Of Education and Psychology. 6, 2, Pp 912-918.

Wagner, J. \& Hollenbeck, J. (2010). Organizational Behavior: SECURING Competitive Advantage. New York: Routledge.

Zarifi, F.; Yousefi, B., Sadeghi Boroujerdi, S. (2012). The Relationship between Organizational Justice and Job Attachment in Physical Education Experts. Sports Management Journal. No. 15, Pp. 157-174. 


\section{Appendix 1: Organizational behavior foundations assessment scale}

\begin{tabular}{|c|c|c|c|c|c|c|}
\hline NO & $\begin{array}{l}\text { To what extent each of the following is effective on the behavior and performance of individuals within } \\
\text { your organization? }\end{array}$ & $\begin{array}{l}\text { Very } \\
\text { high }\end{array}$ & high & medium & low & $\begin{array}{l}\text { Very } \\
\text { low }\end{array}$ \\
\hline 1 & individuals Age & & & & & \\
\hline 2 & individuals Gender & & & & & \\
\hline 3 & Marital status of the individuals & & & & & \\
\hline 4 & Employment status of the individuals & & & & & \\
\hline 5 & individuals Social background & & & & & \\
\hline 6 & Learning new things & & & & & \\
\hline 7 & Their ability to solve problems through insight and experience & & & & & \\
\hline 8 & Their adaptability to work place and new situations & & & & & \\
\hline 9 & Their ability to analyze issues & & & & & \\
\hline \begin{tabular}{|l|l|l}
10 \\
\end{tabular} & Individuals' behavioral (treatment) ability & & & & & \\
\hline \begin{tabular}{|l|l|l}
11 \\
11
\end{tabular} & Individuals' Verbal ability & & & & & \\
\hline 12 & Individuals' mental ability & & & & & \\
\hline 13 & Individuals' intellectual ability & & & & & \\
\hline \begin{tabular}{|l|l|l}
14 \\
14
\end{tabular} & Individuals' job-ability fitness & & & & & \\
\hline \begin{tabular}{|l|l|l}
15 \\
15 \\
\end{tabular} & Social and collective spirit of individuals & & & & & \\
\hline 16 & Individuals' ability to gain the trust of others & & & & & \\
\hline 17 & Individuals' consciousness & & & & & \\
\hline 18 & Individuals curiosity and questing spirit & & & & & \\
\hline \begin{tabular}{|c|}
19 \\
\end{tabular} & Individuals' emotional stability & & & & & \\
\hline \begin{tabular}{|l|l|l}
20 \\
20
\end{tabular} & Individuals' religious beliefs & & & & & \\
\hline \begin{tabular}{|l|l|l}
21 \\
\end{tabular} & Individuals' kind of thinking and feeling about life and the world around (worldview) & & & & & \\
\hline 22 & Individual values & & & & & \\
\hline \begin{tabular}{|l|l|l}
23 \\
23
\end{tabular} & The extent of individuals' commitment to the organization & & & & & \\
\hline 24 & The extent of individuals' job satisfaction & & & & & \\
\hline 25 & Individuals' positive and negative feelings and attitudes toward life and the others & & & & & \\
\hline \begin{tabular}{|l|l|l}
26 \\
26
\end{tabular} & Dissonance between individuals attitude and his/her behavior at work & & & & & \\
\hline 27 & Individuals" perception about organization matters & & & & & \\
\hline 28 & Individuals' mental processing patterns & & & & & \\
\hline 29 & Perceptions of individuals about workplace events & & & & & \\
\hline 30 & Perceptions of individuals about his/her time and place of work & & & & & \\
\hline 31 & General Information obtained by the individual while working & & & & & \\
\hline 32 & Individual work experience & & & & & \\
\hline 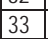 & Individuals' attitudes created at work place & & & & & \\
\hline 34 & Individuals' technical knowledge & & & & & \\
\hline 35 & A variety of individual needs (biological, social, status, independence, etc.) & & & & & \\
\hline 36 & Beliefs one of the individual about causes of problems (linking their cause to themselves or others) & & & & & \\
\hline 37 & Having a purpose in doing things & & & & & \\
\hline 38 & Individuals' belief in doing things properly & & & & & \\
\hline 39 & The role and position of the individual in group & & & & & \\
\hline \begin{tabular}{|l|}
40 \\
\end{tabular} & How close are individuals to each other & & & & & \\
\hline 41 & Rank and position of units & & & & & \\
\hline \begin{tabular}{|l|l}
72 \\
42
\end{tabular} & individuals sense of security and job status & & & & & \\
\hline \begin{tabular}{|l|l}
42 \\
43
\end{tabular} & Numbers of each group and the extent of their friendship and closeness & & & & & \\
\hline 44 & Management's ability to establish relationships with other people & & & & & \\
\hline 45 & Management's ability to penetrate and influence people & & & & & \\
\hline \begin{tabular}{|l|l}
46 \\
\end{tabular} & The ability of managers to motivate their people & & & & & \\
\hline 47 & Individual's skills at establishing relationships with others & & & & & \\
\hline 48 & Individual's ability to share information with others & & & & & \\
\hline 49 & Censorship of news or events by the organization & & & & & \\
\hline 50 & rumors among the individuals & & & & & \\
\hline \begin{tabular}{|l|l|l}
51 & 0 \\
\end{tabular} & Individuals expertise & & & & & \\
\hline \begin{tabular}{|l|l|l}
52 \\
52
\end{tabular} & Individuals' organizational rank & & & & & \\
\hline 53 & Promotion, getting a proper job or post & & & & & \\
\hline 54 & The amount of interest and tolerance among people & & & & & \\
\hline \begin{tabular}{|l|l|l}
55 \\
\end{tabular} & Individuals fear of punishment & & & & & \\
\hline \begin{tabular}{|l|l|l|l}
56 \\
56
\end{tabular} & Individuals' tendency to flattery and scapegoating others & & & & & \\
\hline 57 & $\begin{array}{l}\text { The individuals desire for political game (the disclosure of confidential information and lobbying for or against } \\
\text { others) }\end{array}$ & & & & & \\
\hline 58 & \begin{tabular}{|l|l} 
Incidence of behaviors such as sabotage, riots, and intimidation \\
\end{tabular} & & & & & \\
\hline 59 & Building coalitions with others & & & & & \\
\hline 60 & Differences in tasks & & & & & \\
\hline
\end{tabular}




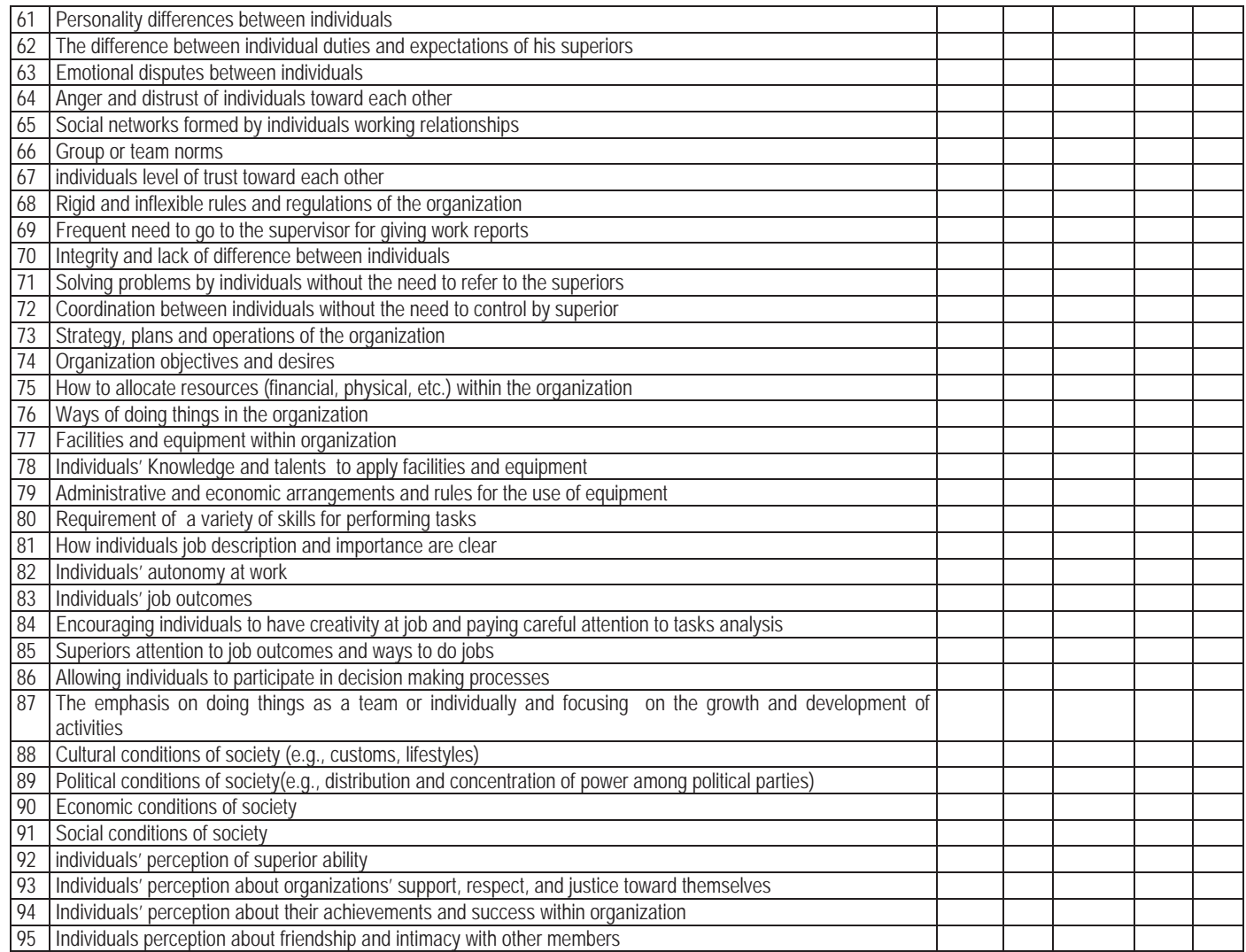


ISSN 2039-2117 (online)

ISSN 2039-9340 (print)
Mediterranean Journal of Social Sciences MCSER Publishing, Rome-Italy
Vol 7 No 6 November 2016 